\title{
Reverse Knowledge Transfer from Overseas Acquisitions: A Survey of Indian MNEs
}

\author{
Smitha R. Nair \\ Lecturer in International Business \& Strategy, Management School, \\ University of Sheffield, Conduit Road, Sheffield, S10 1FL, United Kingdom \\ Email: s.nair@sheffield.ac.uk \\ Mehmet Demirbag* \\ *corresponding author \\ Professor of International Business, \\ Strathclyde Business School, University of Strathclyde, \\ Livingstone Tower, Level 7 \\ 26 Richmond Street, \\ Glasgow, G1 1XH. United Kingdom \\ Tel: +44 1415536004 \\ Fax: +44 1415536162 \\ Email: mehmet.demirbag@strathclyde.ac.uk
}

\author{
Kamel Mellahi \\ Professor of Strategic Management, Warwick Business School, \\ University of Warwick, Coventry, United Kingdom \\ Email: Kamel.Mellahi@wbs.ac.uk
}




\section{Reverse Knowledge Transfer from Overseas Acquisitions: A Survey of Indian MNEs*}

\section{Smitha R Nair • Mehmet Demirbag • Kamel Mellahi}

\section{Abstract:}

- In this paper, we examine the effects of subsidiary level factors on reverse knowledge transfer (RKT) in MNEs from the emerging market of India (EMMNEs). We argue that subsidiary level competencies and capabilities play a vital role in persuading the parent EM-MNEs to initiate the RKT in their attempt to overcome the disadvantages they have. The competency levels of the subsidiary have been captured in terms of the role that the subsidiary has in the network and its host country endowments. In addition, RKT requires the subsidiary units to collaborate closely with the parent EM-MNEs and is also dependent on the extent of complexity of this knowledge.

- The study involves a survey of MNEs from the emerging market of India with overseas acquisitions. We develop a set of hypotheses and test them with the data using OLS regression.

- Results show that higher levels of collaboration facilitate RKT to the parent firm, and this effect is more prominent in high technology and knowledge intensive industries. Also, subsidiaries that hail from host countries with a higher competitive index compared to India and those that perform the role of specialised contributors contribute more towards RKT. In addition, a higher level of knowledge complexity leads to a greater extent of RKT.

\section{Keywords}

Reverse knowledge transfer, emerging market multinationals, subsidiary role, collaboration, subsidiary competence, India.

\section{Authors}

Dr Smitha R Nair

University of Sheffield, Conduit Road, Sheffield, S10 1FL, United Kingdom

Prof. Mehmet Demirbag $(\square)$

\footnotetext{
${ }^{*}$ We would like to thank guest editors and two anonymous reviewers for their insightful comments on an earlier version of this paper.
} 
Strathclyde Business School, University of Strathclyde, Glasgow, G1 1XH, United Kingdom e-mail: mehmet.demirbag@strath.ac.uk

Prof. Kamel Mellahi

Warwick Business School, The University of Warwick, Coventry, CV4 7AL, United Kingdom. 


\section{Introduction}

Emerging markets multinationals (EM-MNEs) have recently emerged as dominant players in the international business landscape (Aulakh 2007; Cuervo-Cazurra 2012; Madhok and Keyhani 2012; Ramamurti 2012; UNCTAD 2012). Many observers view these companies as the new hidden engines of global trade and economic growth (BCG 2012; Bonaglia et al. 2007).

Indian MNEs have been very active in Merger \& Acquisition (M\&A) overseas, indulging in several recent high profile acquisitions such as Tata Steel-Corus, Hindalco-Novelis, Tata Motors-Jaguar \& Land Rover, Dr Reddys-Betapharm and Suzlon-Hansen. Scholars of EM-MNEs have highlighted the importance of their rapid learning from overseas acquisitions, noting the prominent role that subsidiary level knowledge plays in their decision to venture abroad (Bonaglia et al. 2007; Kedia et al. 2012; Li 2003; Mathews 2006). MNEs from India have deliberately followed a strategy of acquiring overseas subsidiaries specifically with a knowledge seeking intent to help them acquire the much needed competitive advantage in global markets which they often lack as latecomers (Bangara et al. 2012; Chandler 2007; Elango and Pattnaik 2011; Kale 2009; Ramamurti 2009). Understandably, Indian MNEs have focused on Western developed markets to tap into the technological advancements and innovations capabilities of firms in these markets (Kumar 2008; Nayyar 2008; Pradhan 2007; Sethi 2009). Thus, this study focuses on knowledge transfer (KT) in Indian MNEs from their overseas acquisitions to the centre.

The international business and management academic community are split on whether or not EM-MNEs represent a "new" breed of multinationals and therefore new theories are required to explain their behaviour (Cuervo-Cazurra 2012; Hennart 2012). On one end of the spectrum are those who argue that existing theories and frameworks are adequately equipped to explain EM-MNEs' behaviour (as explained in detail below), and that although their motives for, and modes of, internationalising tend to be different, this neither generates the need for new theories, nor does it demonstrate that EM-MNEs are a new kind of multinationals (Dunning et al. 2008; Rugman 2008). On the other end of the 
spectrum are those who advocate the need for new theories (Bonaglia et al. 2007; Guillen and Garcia-Canal 2009; Hennart 2012; Li 1998; Lou and Tung 2007; Mathews 2006). In the middle of the spectrum are those who argue for the need of extending current theories and frameworks to explain the behaviours and operations of EM-MNEs (Cuervo-Cazurra 2012; Ramamurti 2012). It is likely that this debate will grow and continue as EM-MNEs deepen their international presence. This study thus extends prior work on reverse knowledge transfer (RKT) - an issue that is of significant importance to EM-MNEs. By so doing, we hope to contribute to this debate by providing empirical evidence on the behaviour of EM-MNEs.

The handful of studies on RKT have investigated the role of organisational mechanisms (Hakanson and Nobel 2001; Persson 2006; Rabbiosi 2011) and subsidiary roles (Ambos et al. 2006; Rabbiosi 2011; Yang et al. 2008) in parent units of DMNEs. The economic development of host country, absorptive capacity (Ambos et al. 2006) and knowledge relevance (Yang et al. 2008) are the other key determinants that have been found to influence RKT. For this study, we attempt to focus on subsidiary competence that is captured at unit level (in terms of subsidiary role) and in terms of host country endowments (relative competitiveness with respect to home country). At the host country level, the focus is on not just the economic development but on the overall relative competitiveness which includes country level endowments like infrastructure, institutions, markets, technology and innovation. These factors are very pertinent for most EM-MNEs since they lag behind their advanced counterparts in several of these aspects. The study involves organisational units that are from diverse socio-cultural settings and additionally, the parent units are from an EM. This means that to facilitate RKT, it is imperative to offset the negative effects of the third world image and promote relational social capital (Nahapiet and Ghoshal 1998; Tsai and Ghoshal 1998) in terms of a shared sense of purpose and goals (collaboration between the parent and subsidiary units). Hence this study looks into the effects of collaboration on RKT that prior studies have not explored. Additionally, the moderating effects of technology and knowledge intensiveness of the industry on collaboration are also analysed. Since the knowledge that the parent EM MNE acquires is crucial to overcoming their inherent weaknesses, the 
parent perception of this knowledge is also vital to RKT. With respect to the knowledge attributes and their effects on RKT, the literature has only looked at the effects of knowledge relevance (Yang et al. 2008) and in this study we look at the complexity of the knowledge from the parent perspective and its effect on RKT. Further, by locating the study in an EM context, the study also contributes to our current understanding of EMMNEs and their intent to learn from their overseas subsidiaries in their attempt to catchup with their global competitors. Towards this, we develop a set of hypotheses and test them using data from MNEs located in India that have acquired overseas subsidiaries.

\section{Theory and Hypothesis}

As discussed earlier, the applicability of extant theories to EM-MNEs has been constantly debated (Cuervo-Cazurra 2012) with one faction arguing for newer theories (Bonaglia et al. 2007; Guillen and Garcia-Canal 2009; Hennart 2012; Li 1998; Lou and Tung 2007; Mathews 2006) and the other faction stating that newer theories are not required (Dunning et al. 2008; Rugman 2008). While the first group claims that the accelerated internationalisation of EM-MNEs is a part of their attempt to acquire the strategic assets and overcome the weaknesses that they have at home; the second group claims that their accelerated internationalisation is only as a result of globalisation because the conditions in which EM-MNEs internationalised are very different when compared to their counterparts in developed countries. There is also a moderate perspective (CuervoCazurra 2012; Ramamurti 2012) who believes in extending some of the existing theories to explain the behaviours and operations of EM-MNEs. Despite these differences in perspectives and the heterogeneities associated with EM-MNEs, it cannot be denied that, in general, EM-MNEs do not always possess the required capabilities to compete in foreign markets. Following the structural changes in many of these EMs in the last decade, they internationalised rapidly to attain the ownership advantages that would in turn lend them the much needed legitimacy that was required to overcome the third world image that they had (Demirbag et al. 2010). Most EM-MNEs struggle with their limitations and weaknesses (Demirbag et al. 2009; 2010; Luo and Tung 2007) with respect to organisational competencies, home country conditions and lack of natural 
resources, in addition to the liability of foreignness (Zaheer 1995) that normally firms have to deal with while operating in foreign markets. These additional weaknesses that they have to overcome since they are from EMs are often referred to as the 'liability of emergingness $^{l,}$ (Madhok and Keyhani 2012). This also meant that they have to engage in extensive catching up in a relatively short span of time to acquire these capabilities (that they did not have) from their overseas acquisitions. However, along with this liability, they also have inherent assets like entrepreneurial drive and learning agility ((Madhok and Keyhani 2012) which are bound to aid their progression to becoming globally competent business leaders. Their global ambitions are thus mainly riding on their efforts towards exploration (learning) and subsequent exploitation (Chittoor et al. 2009) from their overseas acquisitions and hence the need to investigate RKT in such a context.

The lion share of the literature on knowledge flows in MNEs has focussed on the conventional knowledge transfer involving Western MNEs and their overseas subsidiaries. This is because traditionally, subsidiaries have been found to learn from their parent units which in this case were Western MNEs or developed MNES (DMNEs) who ventured overseas to exploit their ownership advantages (proprietary assets) and make use of the location advantages (factor and resource costs) (Mathews 20006). In such situations, the focus is largely on developing subsidiary competencies and to take advantage of the lower operational costs or availability of natural resources in the host location to increase the scale and scope of their operations and their customer base. On the contrary, the growing literature on EM-MNEs suggest that EM-MNEs did not have many of the traditional ownership advantages (globally reputed brands, proprietary knowledge, state of the art production and manufacturing facilities, infrastructure, $R \& D$ and innovation to name a few) that DMNEs exploited when they went overseas (Aulakh 2007; Contractor 2013; Madhok and Keyhani 2012; Mathews 2006). As latecomers to the international scene, the EM-MNEs accumulated these ownership advantages as they

\footnotetext{
${ }^{1}$ Weaknesses external to the firm are underdeveloped markets, unsophisticated customers, weak suppliers, and other input scarcities, infrastructure bottlenecks and institutional voids. Weaknesses internal to the firm are limited global exposure, lower technological and managerial standards, inadequate resources and capabilities, lack of credibility and legitimacy (Madhok and Keyhani 2012).
} 
ventured aboard, often engaging in multiple overseas ventures simultaneously and acquiring companies even larger than them in a shorter time span. This makes it more pertinent to investigate the knowledge flowing into the parent units of EM-MNEs (Reverse Knowledge Transfer or RKT) from their overseas subsidiaries as they play a vital role in the catching up strategies of these MNEs.

Knowledge transfer (KT) literature has largely looked at the barriers and facilitators to knowledge flow within MNEs (Bjorkman et al. 2007; Gupta and Govindarajan 2000; Minabaeva et al. 2003; Mellahi and Collings, 2010; Monteiro et al. 2008; Schulz 2001; Szulanski 1996). Three key antecedents of KT emerge from this body of research. They are (i) organizational characteristics (Bjorkman et al. 2004; Minbaeva 2005; Simonin and Ozsomer 2009) (ii) characteristics of knowledge (Minbaeva 2007; Pak and Park 2004; Pérez-Nordtvedt et al. 2008; Simonin 1999b; Schulz 2003) and (iii) relational aspects between the source and recipient units (Li 2005; Muthuswamy and White 2005; Tsai and Ghoshal 1998). As discussed earlier, most of these studies deal with conventional KT in DMNEs. Hence, the focus of this study is RKT that plays a crucial role in the development of competitive advantage for Indian MNEs. Owing to the disadvantages that EM-MNEs have and their unbalanced diamonds (Asmussen et al. 2009), the double diamond model (Rugman and Verbeke 1993) proposes that the overseas subsidiaries play a vital role in transforming the host country location-bound assets into ownership advantage for the entire MNE (Agostino and Santangelo 2012). Thus the host country location advantages and subsidiary competencies are crucial to EM-MNEs (as latecomers with liability of emergingness) in gaining the much required international competitiveness and is vital for RKT. The existing literature on RKT has not explored the effects of parent's perception of the complexity of knowledge and the effects of organisational collaboration on RKT. This study thus looks into the joint effects of subsidiary roles, host location advantages (relative host country competitiveness), knowledge complexity and collaboration on RKT which has not been examined yet. In the subsequent sections, we discuss each of these variables and their association with RKT in EM-MNEs. 


\section{Subsidiary role}

Subsidiary's role refers to the "set of formal and informal management systems that determine the relationship of the subsidiary to its parent and affiliates" (Birkinshaw, and Morrison 1995). Since the MNE is a network of interconnected units wherein each individual unit has its own role and responsibilities to fulfil, the contribution of each subsidiary towards knowledge inflows and outflows varies according to the assigned role (Gupta and Govindarajan 1991; McGuinness et al. 2013). Using Birkinshaw and Morrison's (1995) typology that is based on geographic scope and autonomy, we look at three subsidiary roles - namely local implementer (LI), specialised contributor (SC), and world mandate (WM) - whose contribution to RKT could potentially vary. LI tend to have "limited geographic scope, typically a single country, and severely constrained product or value-added scope" and their basic role is to "adapt global products to the needs of the local market" (Birkinshaw and Morrison 1995). SC tends to have "considerable expertise in certain specific functions or activities" (Birkinshaw and Morrison 1995). Subsidiaries with WM tend to operate in "a strategically important market and had high levels of resources and expertise" (Birkinshaw and Morrison 1995). The implicit assumption here is that the role envisioned for the subsidiary by the parent EM-MNE is an indication of the superior competence possessed by the subsidiary.

LI are more focussed on local production, and therefore, the possibility of EM parents seeking this knowledge is comparatively lower when compared to SC or subsidiaries with WM. Since subsidiaries with the WM have a wider scope of activities under their purview with more global responsibilities, they tend to be more valuable sources of knowledge for the EM-MNE parent. The SC have a much narrower focus and are in possession of specialised capabilities and has higher levels of interdependence (Birkinshaw and Morrison 1995) with the rest of the units. Generally, subsidiary units functioning as the WM and SC tend to contribute more towards knowledge outflows (Gupta and Govindarajan 1991; 1994), by acting as 'knowledge brokers' helping in diffusing innovation amongst the parent and other units of the MNE (Ambos et al. 2006). Hence EM parents who are in the process of acquiring the competencies required to 
operate in competitive global markets are more likely to be interested in the knowledge residing with WM and SC, as they would be considered more strategically relevant for their operations when compared to LI. This leads to the following hypotheses;

Hypothesis la (Hla): Reverse knowledge flow from the overseas subsidiary to the Indian parent would be more prominent for subsidiaries with a world mandate (WM) when compared to local implementers (LI).

Hypothesis $1 b(H 1 b)$ : Reverse knowledge flow from the overseas subsidiary to the Indian parent would be more prominent for subsidiaries that are specialised contributor (SC) when compared to local implementers (LI).

\section{Relative competitiveness of the host country}

Subsidiaries operate in business environments that consist of suppliers, competitors, customers, government agencies, universities, research organisations and infrastructure, all of which have potential impacts on the development of the unit (Furu 2001). The levels of economic development of the host country influence the extent of knowledge flows (Gupta and Govindarajan 2000; Monterio et al. 2008). In this case, the relative economic development of the host country when compared to the home country influences the way in which the parent EM-MNE perceives the knowledge stock of the subsidiary (Gupta and Govindarajan 2000). In a scenario when the host countries are relatively economically advanced compared to the home country, they are more likely to be part of superior industrial clusters and other networks that possess advance knowledge (Ambos et al. 2006; Demirbag and Glaister 2010), which in turn provides the EM-MNEs with competitive advantage (Pillai 2006). This proves to be crucial for the EM-MNEs in overcoming their inherent weaknesses. The diamond network model (Rugman and Verbeke 1993) also talks about how home countries have unbalanced diamonds as they are strong in some dimensions and weak in others (Asmussen et al. 2009) and how they tap into the stronger dimensions available in more competitive host countries via their subsidiaries. Subsidiaries from more competitive countries are likely to be viewed as trend-setters who are more efficient when it comes to technical, managerial and 
marketing expertise. This makes the knowledge held by such subsidiaries very desirable and attractive to the EM-MNE parent and it is likely increase the outflow of knowledge from the subsidiary to the parent. For instance, recent evidence show that outward knowledge flow from subsidiaries in economically developed country like Finland is significantly higher than those from China ( $\mathrm{Li}$ et al. 2007). This leads to the following hypothesis;

Hypothesis $2(\mathrm{H} 2)$ : Reverse knowledge flow from the overseas subsidiary to the Indian parent is positively associated with the competitiveness of the host country compared to the home country.

\section{Collaboration between organisational units}

The positive effect of social capital on organisational KT in terms of social interaction, trust and shared vision has attracted a lot of attention (Dhanaraj et al. 2004; Muthuswamy and White 2005; Pak and Park 2004; Tsai and Ghoshal 1998). Working closely in groups fosters an environment favourable for knowledge exchanges (Brown and Duguid 1991). By way of socialisation, organisational units identify themselves more to the corporate goals and values. Social interactions and sharing of experiences helps the units to develop shared cognitive models (Grant 1996) which in turn open up communication between the units. Joint activities involving different units creates a shared understanding of the other unit's technical capabilities and "who knows what'. Overall, close collaboration between units of MNEs help overcome the cultural and institutional barriers that could hinder KT between the units (Simonin 1999a; Taifi and Passiante 2012). For the EM-MNE parent to benefit, the RKT must be accompanied by collaboration between unites and internal transfer mechanisms (Chen et al. 2012).Hence we propose the following hypothesis;

Hypothesis 3 (H3): Reverse knowledge flow from the overseas subsidiary to the Indian parent will be positively related to the collaboration between the subsidiary and the parent units.

The levels of collaboration between organisational units also depend, to a large extent, on the industry to which they belong. In firms belonging to high and medium technology and 
knowledge intensive sectors, knowledge from different streams need to be integrated (Prahalad and Hamel 1990). Knowledge in such industries, in many cases, is embedded in host local networks (Almeida and Kogut 1999) and tacit in nature (Simonin 1999a; Zander and Kogut 1995) which require channels for transfer and frequent interaction between the EM-MNE and its developed market subsidiary (Chen et al. 2012). These are industries, where typically, EM-MNEs may not have firm specific advantages for asset exploitation, but could be seeking technology based resources through an acquired developed market based subsidiary (Bertoni et al. 2008). These are also fast changing industries requiring such mechanisms of interactions (Chen et al. 2012). Such industries tend to be very innovative and in constant need to evolve and upgrade their knowledge (Kumar and Singh 2008). All this makes it more crucial for such industries to rely more on collaborative projects to bring in their specialised knowledge and put them to use. This will lead to more knowledge transactions than in firms that are from low technology and less knowledge intense sectors. Hence we propose;

Hypothesis $4 a(\mathrm{H} 4 \mathrm{a})$ : The positive effect of reverse knowledge flow on collaboration will be greater for Indian MNEs that are from high technology and knowledge intensive sectors when compared to low technology and knowledge intensive sectors.

Hypothesis $4 b(H 4 b)$ : The positive effect of reverse knowledge flow on collaboration will be greater for Indian MNEs that are from medium technology and knowledge intensive sectors when compared to low technology and knowledge intensive sectors.

\section{Knowledge Complexity}

Knowledge complexity deals with the comprehension of the knowledge and is also closely associated with the width that the knowledge spans (Grant 1996). Hence, knowledge could prove to be more complex especially when it spans across multiple domains of expertise. It then becomes difficult to familiarise with all of the various involved components (Simonin 1999b) so as to get the complete picture. Hence this could prove to be a hindrance to knowledge flows (Pak and Park 2004; Simonin 1999b). Here the complexity contributes to "stickiness" of knowledge or the difficulty to transfer 
knowledge. This makes the knowledge less prone to imitation and hence cannot be easily substituted. However, one also needs to take into account the fact that such knowledge is crucial for the EM-MNEs especially in their capability building and catching-up strategies.

Although the influence of knowledge aspects on conventional KT has been looked into, the effect on RKT still needs to be better understood. This is because unlike conventional KT, RKT needs the parent to be persuaded (Yang et al. 2008) to initiate the RKT. Evaluation of the subsidiary knowledge characteristics by the parent is crucial when it comes to this decision related to RKT. The EM-MNE parent could be deterred from attempting RKT that involves very complex subsidiary knowledge because of the associated levels of difficulty to comprehend. Hence it is also pertinent that the knowledge complexity is evaluated from the parent EM-MNE's perspective. As RKT is based on the parent unit's prerogative, the complexity of knowledge as perceived by them influences the transfer. The more difficult the transferability of the knowledge from a parent EM-MNE's perspective, there is likely to be more reluctance associated with attempting the same. Hence the study proposes;

Hypothesis 5 (H5): Reverse knowledge flow from the overseas subsidiary to the Indian parent will be negatively related to the complexity associated with the subsidiary knowledge as perceived by the parent.

\section{Research Method}

\section{Data Collection}

Data was collected for this study over a period of 6 months (August 2011 to January 2012) by conducting a survey of Indian MNEs with overseas acquisitions. Indian overseas acquisitions have been chosen for several reasons. Their accelerated internationalization patterns - mainly via acquisitions with majority ownership, host locations that are very geographically dispersed with a pronounced shift towards developed economies, the large proportion of privately owned MNEs from technology 
and knowledge intensive sectors and the presence of influential entrepreneurial business groups have attracted attention from both media (BCG 2012; Business Week 2006; Economist 2008; Girod et al. 2009) and academia (Aulakh 2007; Cuervo-Cazurra 2012; Contractor 2013; Gaur and Kumar 2010; Jormanaien and Kovashnikov 2010; Khanna and Palepu 2006; Sethi 2009). Additionally, Indian MNEs account for the most number of finalised overseas deals (WIR 2010) when compared to other BRIC countries. Also, there is evidence to suggest that generally Indian MNEs have been more successful than their Chinese counterparts at integrating their acquisitions (Gupta and Wang 2009) and providing more value to their shareholders (Kale 2009; Ray and Gubbi 2009). The questionnaire was administered to 329 Indian MNEs and after two to three rounds of follow-ups, we received 114 responses out of which 101 were usable. The firm level response rate was $31 \%$. Non response bias was checked with a t-test which confirmed that non-respondent and respondent firms did not significantly differ in terms of pertinent firm related parameters ${ }^{2}$ (Ambos and Ambos 2009). The results thus rule out non response bias for this study. The respondents were also assured of complete confidentiality with regards to the responses provided.

The list of 329 Indian MNEs was compiled from FICCI $^{3}$ reports (FICCI 2006; FICCI and Grant Thornton 2010) that comprise of the mergers and acquisitions made by Indian MNEs between 2000 and $2010^{4}$. The FICCI list (2006) of Indian MNEs had their acquisitions in various host countries largely dominated by US (33.3\%), UK (13.1\%), Germany (6.2\%), Australia (5.2\%), France (3.6\%) and Singapore (3.3\%). With regards to their acquisition in developing countries, they are located predominantly in China (2\%), Brazil (1.3\%), Egypt (1.3\%), South Africa (1.3\%) and Thailand (1.3\%). Prior to the administration of the questionnaire, a pre-test was done on managers from Indian firms and senior academics. Local research teams in India were also utilised to identify potential

\footnotetext{
${ }^{2}$ Age, revenue figures (2010-2011), profit-loss figures (2010-2011)

${ }^{3}$ Federation of Indian Chambers of Commerce and Industry

${ }^{4}$ Supplemented also with Grant Thornton, 2010; IBEF, 2006; Mape, 2006; BCG, 2009; Grant Thornton (M\&A) Dealtrackers 2005 to 2010
} 
respondents, establish contacts and to administer the surveys. $71 \%$ of the respondents were senior managers (CEOs, COOs, CIOs, VPs, GMs and Business Heads) and 29\% were middle level managers (heading departments or functions). The average respondent tenure with their respective organisation is 9 years. The majority of the respondent Indian MNEs were from IT (17\%), Pharmaceutical (20\%) and Automotive (12\%) sectors and the subsidiaries were located mostly in Unites States (32\%), UK (19\%) and Germany (9\%). The mean age of the respondent MNEs was 37 years. The characteristics of sample Indian MNEs are summarized in Table 1.

\section{Insert Table 1 around here}

Most studies on KT and specifically those on RKT (Ambos et al. 2006; Hakanson and Nobel 2001; Persson 2006; Rabbiosi 2011; Yang et al. 2008) have been nodal studies (involves either the source or recipient unit) based on primary data or based on patent data (Frost and Zhou 2005). This is mainly due to the practical difficulties associated with collecting data from both units of the dyad. With regards to RKT, the recipient unit is the parent unit and hence for a nodal study, it would be more meaningful to capture RKT from the parent perspective (Ambos et al. 2006; Rabbiosi 2011) as the recipient of the transferred knowledge has a better understanding of the extent of the transmitted knowledge that has been actually received at their end. Since this study is on EM-MNEs from India, it is further imperative to understand the process from the parent EM-MNE units located in India. Hence the survey was conducted at the parent unit level in India and hence the measures of all variables were captured from a parent perspective. However, getting the subsidiary perspective (source) would have provided much more depth and meaning to this study and this is a limitation with this study. In addition, most studies on KT target the knowledge inflow/outflow into/from a focal subsidiary (Bjorkman et al. 2004; Gupta and Govindarajan 2000). For this study, since the parent perspective has been captured, the set of questions were posed for a focal subsidiary that the respondent senior executive was most familiar with so as to enable the respondent to give accurate estimates of the extent of RKT and other variables involved. This enables to 
control for subsidiary size, age and other such subsidiary level variables to be captured for a specific subsidiary.

\section{Variable Measures}

\section{Dependent Variable}

The dependent variable RKT was measured using three items 'our subsidiary provides us with knowledge and skills' (Gupta and Govindarajan 2000) in the areas (a) technological (b) marketing and (c) management using a seven-point Likert scale ( $1=$ not at all to $7=\mathrm{a}$ very great deal). The scales used for the variables in the study have been provided in Appendix A.

\section{Independent Variables}

Collaboration between the parent and the subsidiary unit was measured (Lee and Choi 2003; Richey and Autry 2009) with four items. A seven-point Likert scale (1=strongly disagree to $7=$ strongly agree) was used. Knowledge complexity was measured for the three different knowledge types using the scale from Simonin (1999b).

For subsidiary role, respondents were asked to choose the category that the subsidiary belongs to viz. world mandate, specialised contributor or local implementer (Birkinshaw and Morrison 1995). The respondents were provided with appropriate descriptions pertaining to each of the roles. In terms of the subsidiary roles, the data had subsidiaries belonging to all different roles viz. Strategic contributor (41\%), World Mandate (29\%) and Local Implementers (30\%) indicating that the set of subsidiaries chosen by the respondents were heterogeneous ${ }^{5}$. This heterogeneity can also be observed in terms of their age, host location and size (Table 1).

\footnotetext{
${ }^{5}$ We would like to thank an anonymous referee for this helpful suggestion. From the FICCI list of India M\&As (secondary data) and based on the information in the company websites and press releases of these acquisitions, we arrived at a qualitative judgment on the subsidiary mandate for 60 of these acquisitions (chosen randomly). It was seen that based on this exercise, $23 \%$ of the subsidiaries had a world mandate, $32 \%$ were local implementers and $45 \%$ were strategic contributors. This is not very different from the pattern seen in the choice of subsidiaries by our respondents.
} 
Secondary data was used as a measure of competitiveness index at the country level which was taken from the global competitiveness report (2011-2012) released by World Economic Forum (WEF). The ratio of the WEF scores (as provided in the world competitiveness report 2011-2012) of the host country to that of the home country have been used as a measure of relative competitiveness ${ }^{6}$.

\section{Control Variables}

Firm level control variables: Control variables at the firm level that have been used in the study include the size (number of employees), age (year established) of the parent as well as the subsidiary and the international experience of the parent (years since first international venture). Logarithmic transformations were used for all of the above (to address the skewness in data). The absorptive capacity of the parent unit was also controlled for as this is seen to be one of the main drivers of KT (Gupta and Govindarajan 2000). The scale used for absorptive capacity was taken from Pak and Park (2004). The mode of establishment was controlled for using dummy variables that were created for three main establishment modes which include greenfield, brownfield, and mergers (reference group).

Industry level control variables: To control for the industry level effects, we grouped the respondent firms into (i) high technology and highly knowledge intensive (ii) medium technology and knowledge intensive and (iii) low technology and less knowledge intensive. This categorisation ${ }^{7}$ (Garcia-Manjon and Romero-Merino 2012) is based on the NACE code.

\footnotetext{
${ }^{6}$ Based on the 12 pillars of Institution, Infrastructure, Macroeconomic environment, Health \& Primary Education, Higher Education \& Training, Goods market efficiency, Labor market efficiency, Financial market development, Technological Readiness, Market Size, Business Sophistication, Innovation

7 It has been developed by the OECD and Eurostat (available on the web at http://ec.europa.eu/environment/emas/pdf/general/nacecodes_en.pdf)
} 
Country level control variable: Finally, we also controlled for cultural distance (Kogut and Singh 1988) between home and host countries based on Hofstede's (1980) four cultural dimensions.

\section{Validity and Reliability}

The results of the confirmatory factor analysis (CFA) have been provided in Table 2 (SmartPLS V2.0 (Ringle et al. 2005) was used). It was found that the outer loadings ( $\geq$ $0.7)$ of the items on the construct are significant $(\mathrm{p}<.01)$ and are also the highest on the construct it measures when compared to their loadings on other constructs (Chin 1998). The values for composite reliability ( $C R \geq 0.7$ ), average variance extracted (AVE $\geq 0.5$ ) and Cronbach's alpha $(\alpha \geq 7)$ establish the convergent validity and reliability (Bagozzi and Yi 1988; Nunnally 1978) for the latent construct measures. The Fornell-Larcker criterion (Fornell and Larcker 1981) was also checked and found to be compliant, which is an indication of the discriminant validity of the measures. We also compared our primary data with secondary data to improve the validity of our findings. We examined patterns of subsidiary mandate expressed by respondents in our survey and the patterns that emerged from the secondary dataset as a result of a qualitative judgement by three assessors ${ }^{\mathrm{i}}$.

Insert Table 2 around here

\section{Empirical Results and Discussions}

Table 3 gives the descriptive statistics that includes the correlations between the variables. Since the correlations are all below 0.7 , which indicates that multi-collinearity might not be an issue. However, to be more precise, the VIF (Variance Tolerance Factor) was also checked to make sure that they are less than 10 confirming that multicollinearity is not a problem (Hair et al. 1995). OLS (Ordinary Least Squares) regression was performed to test the hypotheses as given in Table 4.

Insert Table 3 around here 


\section{Insert Table 4 around here}

As shown in Table 4, three models have been analysed and the F-statistics indicate that all of them are significant $(\mathrm{p} \leq .001)$. Model 1 and 2 illustrate the individual influence of the control variables and with the independent variables respectively on RKT. Model 2 has been used to test the hypotheses 1, 2, 3 and 5. In addition, because of the smaller sample size, these models were also analysed using PLS modelling (using SmartPLS V2.0) which further confirmed the findings and trends detected in this study. Model 3 includes that interaction effects to test hypotheses $4 \mathrm{a}$ and $4 \mathrm{~b}$.

The regression results indicate that the hypotheses relating ( $\mathrm{H} 1 \mathrm{a}$ and $\mathrm{H} 1 \mathrm{~b})$ to the effect of subsidiary role on RKT is only partially supported. It could be seen that the result holds well $(\beta=.468, p=.077)$ only for SC $(\mathrm{H} 1 \mathrm{~b})$ and is not supported $(\mathrm{p}=0.238)$ for subsidiaries with world mandate (H1a). This means that RKT from subsidiaries with world mandate is not significantly greater than that of local implementer while RKT from subsidiaries who are specialised contributor is significantly greater than that of local implementer. Gupta and Govindarajan (1994) propose that knowledge outflows are higher from subsidiaries that perform the role of global innovators and integrated players, since they serve as fountainhead of knowledge for other units. However, studies by Ambos et al. (2006) show a significant effect on reverse transfer benefits only when it comes to integrated players while the effect was not significant in global innovators. A comparison of Gupta and Govindarajan (1994) typology, with that of Birkinshaw and Morrison (1995) show that; integrated players are similar to specialised contributor and global innovators are similar to subsidiaries with world mandate (Harzing and Noorderhaven 2006). The results indicate that Indian MNEs are keener in transferring the knowledge from specialised contributor subsidiaries. MNEs in general have been increasingly orienting their $R \& D$ activities ( $R \& D$ hub) towards international markets and knowledge centres (as decentralised units) and many of such R\&D centres are controlled by the central R\&D unit located at home base (Gassman and von Zedtwitz 1999). Indian MNEs have also utilised such opportunities that come with the global dispersion of R\&D activities and have acquired such overseas units (knowledge power houses) with clear 
mandates (Bhaumik and Driffield 2011; Chittoor and Ray 2007; Elango and Pattnaik 2011). Such acquisitions are a vital part of their catching up strategies which enables them to compete much more effectively with their advanced counterparts (DMNEs).

The second hypothesis (H2) looks at the effect of relative competitiveness of the host country. The results illustrate that $\mathrm{H} 2$ is supported $(\beta=2.245, \mathrm{p}=.052)$ indicating that greater the overall competitiveness of the host country when compared to the home country, greater will be the RKT. Subsidiaries from such advanced countries are likely to be more competent and in possession of superior knowledge when compared to the Indian EM-MNE. The acquisitions of Indian EM-MNEs also show a significant dominance in the more advanced western markets (Sethi 2009) which is further evidence of this pattern (south-north acquisition) of knowledge seeking OFDI (Demirbag et al. 2009). Further, studies also indicate that subsidiaries from advanced countries contribute more towards knowledge outflows (Ambos et al. 2006) while those from less advanced countries are more involved with knowledge inflows (Gupta and Govindarajan 2000). However, this study accounts for a number of indicators that cover the institutional and market environment of the host countries besides the economic indicators. The host country endowments in terms of being highly innovative locations with world class research, local skills and expertise, customers and supplier networks are very vital for the Indian MNEs. In their attempt to overcome their liability of emergingness (Madhok and Keyhani 2012), Indian MNEs look towards knowledge from host locations that are more competitive in terms of cutting-edge technologies and more advanced markets with better institutional environments to overcome their liability of emergingness. They seek complementary diamonds (Agostino and Santangelo 2012; Rugman and Verbeke 1993) and especially intangible assets in host locations that have specific advantages that they can derive competitiveness from. Indian MNEs have more opportunities for learning from such host locations in terms of operating in advanced markets with better infrastructure and institutional environment. Several Indian IT firms have been successful in setting up operational facilities and infrastructure in India along the lines of similar facilities in US and other advanced countries. This further indicates their learning from their operations and acquisitions in that part of the world. 
The analysis also reveals the positive effects of collaboration between the parent and the subsidiary units on RKT as stated in $\mathrm{H} 3(\beta=.265, \mathrm{p}=.052)$. Collaborative culture in an organisation fosters knowledge creation by way of improved knowledge exchanges (Lee and Choi 2003). Collaboration brings organisational units closer which in turn make them more open and willing to each other's ideas and experiences. This reduces potential differences and improves the shared understanding between the organisational units. In the context of this study based in the EM of India, where the involved units are quite dissimilar in their socio-cultural background, the social ties and shared vision resulting from such collaborations prove to be fruitful in blurring the boundaries between the units. This aspect is even more relevant in contexts where the subsidiaries are from the western countries who have more of an individualistic culture (Eaton and Louw 2000) when compared to India which typically has a collectivist culture.

The moderating effects of industry level variables on the positive impact of collaboration on RKT have been tested with hypothesis $\mathrm{H} 4 \mathrm{a}$ and $\mathrm{H} 4 \mathrm{~b}$. The results provide support only for $\mathrm{H} 4 \mathrm{a}$ ( $\beta=.515, \mathrm{p}=.082$ ) which implies that the positive effect of collaboration on RKT is more prominent in the high tech and highly knowledge intensive sectors when compared to low tech and low knowledge intensive sectors. However, the effect was not significant $(\mathrm{p}=.148)$ for industries that belong to medium tech and knowledge intensive sectors. High tech and knowledge intensive sectors often require more collaboration between diverse streams of knowledge for their operations and development when compared to low tech and low knowledge intensive sectors. Such sectors are generally more R\&D intensive and rely on cutting edge technology and innovation. Indian MNEs especially from the automotive and pharmaceutical sectors belong to this category and have benefited immensely from their overseas acquisitions when it comes to advancing their R\&D operations and using this knowledge to develop their own products in home country (Bower and Sulej 2005; Gert 2010). Hence RKT in such units will also demand more collaboration between the associated units which is indicated by the results.

Hypothesis H5 deals with the negative effect of knowledge complexity on RKT. However, the results indicate a strong positive effect of knowledge complexity on RKT 
( $\beta=.491, \mathrm{p}=.000)$. Prior studies see such knowledge attributes as deterrents to conventional knowledge flows (Simonin 1999a, b; 2004). Hence, this is one of the most surprising and interesting findings from this study. The results imply that as the complexity of the knowledge held by the subsidiary increases, the extent of RKT also increases. This could be attributed to the fact that the Indian EM-MNEs would have attempted to transfer the knowledge residing with their subsidiaries irrespective of the associated complexity levels. However in this scenario, since to acquire knowledge that is more complex also tends to be more difficult, the parent EM-MNE would have to resort to a greater extent of knowledge transfer to materialise the same. This could be the potential cause for the positive relationship between knowledge complexity and RKT. The fact that the Indian EM-MNE had to resort to this RKT in spite of the associated complexity throws light on the fact that they were prompted to do this to close their capability gap with developed country MNEs. This indicates that the Indian MNEs are unperturbed by the complexity of the knowledge and they attempt to transfer it despite the associated complexity if they reckon that the knowledge will help them in overcoming their liability of emergingness (Madhok and Keyhani 2012) and gain the much needed competitive advantage. This indicates their attempt at springboarding (Lou and Tung, 2007) and learning effectively and leverage (LLL framework) the resources from their overseas linkages (Mathews 2006).

Regarding the control variables, cultural distance had a significant negative effect on RKT ( $\beta=-.619, p=.004)$. This confirms prior studies suggesting that cultural distance could be a hindrance to KT (Cho and Lee 2004; Simonin 1999b). This could be attributed to the fact that cultural differences could cause conflicts and misunderstandings amongst organisational units that are possibly rooted in their own national and organisational cultures.

\section{Conclusion}

This study attempts to bring together two diverse streams of literature - on emerging markets and reverse knowledge transfer. Conventional KT has been extensively analysed 
in the international business and strategic management literature. However, the same cannot be said about RKT and more so in the context of EM-MNEs, since they are vital to their catching up strategies in pursuit of global ambitions. Based on the international expansion patterns of Indian MNEs that are largely motivated by the possibility of knowledge acquisitions; we attempt to analyse the joint effects of subsidiary role, relative competitiveness of host country, knowledge complexity and collaboration on RKT. Although the effects of subsidiary role have been investigated by earlier studies, this study attempts to capture competency of the subsidiary in terms of its mandate as well as the host country endowments which has not been explored in the extant RKT literature. In addition, the effects of collaboration between the culturally and socially diverse organisational units and the parent perception of the knowledge complexity, which have been largely overlooked in the existing literature on RKT, have been explored in this study. This study thus extends our current understanding of RKT in MNEs and more specifically in the context of EM-MNEs.

As discussed earlier, the literature on EMs is caught in debates surrounding the need for newer theories to explain their internationalisation. Along the same lines, the results from this study prescribe to the more moderate view that EM-MNEs are not always different from the DMNEs. While some of the results from this study could very well be the same for DMNEs, it could be also be different in some other aspects. The results suggest that Indian firms are more interested in the knowledge residing with their Specialised Contributors. This means that they are on the lookout for very specific skills that these subsidiaries possess again confirming their strategy on acquiring specific capabilities that they do not possess to overcome their liability of emergingness (Madhok and Keyhani 2102). Acquisitions in well-endowed host countries provide the Indian MNEs with sophisticated markets and infrastructure, innovative technologies and skills and better managerial capabilities. This helps them tap into the local knowledge within the industrial clusters and utilise the benefits from local networks in the host country through their subsidiaries. This could be more pertinent to MNEs from highly technology and knowledge intensive industries that would benefit more from such advanced and competitive environments since they are continuously seeking better knowledge, skill and 
technology. The Indian MNEs from the pharmaceutical and automotive sectors that are very active in the M\&A scene mostly fall into this category. While acquisitions in ${ }^{8} \mathrm{UK}$ helped Tata Motor's transformation into a formidable global player from a late entrant in the passenger car segment (Gert 2010), acquiring overseas R\&D labs (in US and Western Europe) are definitely aiding Dr Reddys Labs and Ranbaxy with their drug discovery capabilities (Bower and Sulej 2005). Such acquisitions have provided the Indian MNEs with operational synergies in addition to the well-equipped R\&D facilities, advanced knowledge and a global footprint.

Further, collaborations between the Indian parent and their overseas subsidiaries also help them achieve the coordination they need to carry out the RKT. This is even more pertinent for the parent units located in India with their overseas units located mostly in developed parts of the world. The differences in organisational cultures and business practices between these units requires them to have shared sense of purpose and understanding in order to be able to take advantage of the potential operational synergies. Tata Steel had established joint forums with Corus to enable collaborations that would enable sharing of technical knowledge and best practices. This helped Tata Steel to reduce the heating time of its coke ovens (Kale et al. 2009). The effects of such collaborations are again more pronounced in high tech and highly knowledge intensive sectors as indicated by the results. Parent-subsidiary collaborations may prove to be advantageous in high tech industries where knowledge may be embedded in the subsidiary organisation as well as their local networks (Chen et al 2012). Further, the diverse streams of technology and knowledge domains that need to be integrated for such high tech industries necessitate the need for higher levels of collaboration. One of the surprising and interesting results from this study, which sets apart EM-MNEs from DMNEs, is with regards to knowledge complexity and its effects on RKT. In general, this knowledge attribute is found to hamper knowledge flows while this study suggests that EM-MNEs are not intimated by the complexity of knowledge which in turn could prove

\footnotetext{
${ }^{8}$ European Technical Centre in UK (2005), INCAT International in UK (2005) and Jaguar \& Land Rover in UK (2008)
} 
to be more valuable for them. The fact that they are desperate to overcome their weaknesses and disadvantages associated with emerging markets prompts them to attempt RKT despite the associated knowledge complexity. Such attempts by Indian MNEs provide support to the newer IB and management views like spring board perspective (Lou and Tung 2007), LLL framework (Mathews 2006) and liability of emergingness (Madhok and Keyhani 2012) that throw light on the relevance of RKT in the catching up strategies of EM-MNEs and their learning from overseas acquisitions. This is also an indication of their assets discussed earlier with respect to their learning agility and their entrepreneurial drive to satisfy their global ambitions despite their liability of emergingness. This also suggests the need to look more into the knowledge attributes in studies pertaining to knowledge transfers especially in EMs.

EM-MNEs could benefit from acquisitions in host countries which are stronger in dimensions that they have disadvantages in. This would help the EM-MNEs to overcome their inherent weaknesses specifically with respect to unbalanced diamonds (Rugman and Verbeke 1993). However, this is also dependent on several other firm level factors, nature of the industry and the host country endowments available. This trend is already quite predominant with Indian MNEs who have majority of their overseas acquisitions in US and UK. This study offers interesting and valuable empirical findings on RKT from acquired subsidiaries of Indian MNEs to their parent firms; however, a degree of caution should be exercised when interpreting the results and generalising this for all EM-MNEs. Since EM-MNEs are not a heterogeneous group (Ramamurti 2009), these results could vary based on the nature of the firms (and the industry) that are involved in overseas M\&As, the extent of catching-up that they need to do which in turn is based on their firm specific advantages and the capability gap that they have with other world players, their institutional environment, entrepreneurial drive and vision, acquisition strategies with respect to location choices and the post-acquisition approach to integration. Another limitation with this study is the limited sample size that the single EM of India offers. Hence conducting similar studies in other emerging markets like China, Russia and Brazil will help generalise these results in terms of a larger group of EM-MNEs and provide larger sample sizes. The study has further investigated the determinants of RKT from a 
nodal perspective (parent firm perspective only) and hence considering all these limitations, the findings should be considered exploratory in nature. Accordingly, it would be more meaningful for future studies to examine the dyadic perspective in order to develop a comprehensive picture. Future research could also consider how the other EM-MNEs' subsidiaries in the home country benefit from knowledge transfer from overseas sister subsidiaries. 


\section{References}

Almeida, P., \& Kogut, B. (1999). Localization of knowledge and the mobility of engineers in regional networks. Management Science, 45(7), 905-917.

Ambos, T. C., \& Ambos, B. (2009). The impact of distance on knowledge transfer effectiveness in multinational corporations. Journal of International Management, 15, 114.

Ambos, T. C., Ambos, B., \& Schlegelmilch, B. B. (2006). Learning From Foreign Subsidiaries: An Empirical Investigation Of Headquarters' Benefits From Reverse Knowledge Transfers. International Business Review, 15, 294-312.

Asmussen, C. G., Pedersen, T., \& Dhanaraj, C. (2009). Host-country environment and subsidiary competence: Extending the diamond network model. Journal of International Business Studies, 40, 42-57.

Aulakh, P. (2007). Emerging multinationals from developing economies: Motivations, paths and performance. Journal of International Management, 13, 235-240.

Bagozzi, R. P., \& Yi, Y. (1988). On the evaluation of structural equation models. Journal of the Academy of Marketing Science, 16 (1), 74-94.

Bangara, A., Freeman, S., \& Schroder, W. (2012). Legitimacy and accelerated internationalisation: An Indian perspective. Journal of World Business, 47, 623-634.

BCG (2012), The 2011 BCG Global Challengers: Companies on the Move: Rising Stars from Rapidly Developing Economies Are Reshaping Global Industries, https://www.bcgperspectives.com/content/articles/globalization_companies_on_the_mov e_2011_global_challengers/. Accessed June 2012.

Bertoni, F., Elia, S., \& Rabbiosi, L. (2008). Driver of acquisitions from BRICs to advanced countries: firm level evidence. DIG-Politecnico di Milano Working Paper.

Birkinshaw, J., \& Morrison, A. (1995). Configurations of strategy and structure in subsidiaries of multinational corporations. Journal of International Business Studies, 26, 729-754.

Björkman, I., Barner-Rasmussen, W., \& Li, L. (2004). Managing Knowledge Transfer in MNCs: The Impact of Headquarters Control Mechanisms. Journal of International Business Studies, 35(5), 443-455.

Björkman, I., Fey, C. F., \& Park, H. J. (2007). Institutional theory and MNC subsidiary HRM practices: Evidence from a three-country study. Journal of International Business Studies, 38(3), 430-446.

Bonaglia, F., Goldstein, A., \& Mathews, J. A. (2007). Accelerated internationalization by emerging markets' multinationals: the case of the white goods sector. Journal of World Business, 42, 369.

Bower, D. J., \& Sulej, J. (2005). The Indian Challenge: The Evolution of a Successful New Global Strategy in the Pharmaceutical Industry. Innogen Working Paper, No. 21. 
Brown, J. S., \& Duguid, P. (1991). Organizational Learning and Communities-ofPractice: Toward a Unified View of Working, Learning, and Innovation. Organization Science, 2(1), 40-57.

Business Week, (2006), Emerging giants, Cover story, July 31.

Chandler, C. (2007). India's global reach. Fortune, 156(8), 151-158.

Chen, V. Z., Li, J., \& Shapiro, D. M. (2012). International reverse spillover effects on parent firms: Evidences from emerging market MNEs in developed markets. European Management Journal, 30, 204-218.

Chin, W. W. (1998). The partial least squares approach to structural equation modelling. In Marcoulides, G. A. (Ed.), Modern methods for business research (pp. 295-336). Lawrence Erlbaum Associates, New Jersey.

Chittoor, R., \& Ray, S. (2007). Internalization Paths of Indian Pharmaceutical firms - A strategic group analysis, Journal of International Management, 13, 338-355.

Chittoor, R., Sarkar, M. B., Ray, S., \& Aulakh, P. S. (2009). Third World Copycats to Emerging Multinationals: Institutional Changes and Organizational Transformation in the Indian Pharmaceutical Industry. Organization Science, 20 (1), 187-205.

Cho, K. R. \& Lee, J. (2004). Firm Characteristics and MNC's Intra-network Knowledge Sharing. Management International Review; 44(4), 435-455.

Contractor, F. J. (2013) "Punching Above Their Weight": The Sources of Competitive Advantage for Emerging Market Multinationals. International Journal of Emerging Markets, 8 (4), 304-328.

Cuervo-Cazura, A. (2012). Extending theory by analyzing developing country multinational companies: Solving the Goldilocks debate. Global Strategy Journal, 2 (3), 153-167.

D’Agostino, L. M., \& Santangelo, G. D. (2012). Do Overseas R\&D Laboratories in Emerging Markets Contribute to Home Knowledge Creation? An Extension of the Double Diamond Model. Management International Review, 52, 251-273.

Demirbag, M., \& Glaister, K. (2010).Factors determining offshore location choice for R\&D projects: A comparative study of TRIAD regions, Journal of Management Studies, 47(8): 1534-1560.

Demirbag, M., McGuinness, M., \& Altay, H (2010) Perceptions of institutional environment and entry mode: FDI from an emerging country, Management International Review, 50(2): 207-240.

Demirbag, M., Tatoglu, E., \& Glaister, K. (2009). Equity-based entry modes of emerging country multinationals: Lessons from Turkey, Journal of World Business, 44(4):445-462.

Dhanaraj, C., Lyles, M. A., Steensma, H. K., \& Tihanyi, L. (2004). Managing Tacit and Explicit Knowledge Transfer In IJVs: The Role Of Relational Embeddedness And The Impact On Performance. Journal of International Business Studies, 35, 428-442. 
Dunning, J. H., Kim, C., \& Park, D. (2008). Old wine in new bottles: a comparison of emerging-market TNCs today and developed-country TNCs thirty years ago. In The Rise of Transnational Corporations from Emerging Markets: Threat or Opportunity? Sauvant, K. (ed). Edward Elgar: Northampton, MA

Eaton, L., \& Louw, J. (2000). Culture and Self in South Africa: IndividualismCollectivism Predictions. The Journal of Social Psychology, 140(2), 210-217.

Economist (2008). Wind of change, Emerging-market multinationals, January 10.

Elango, B., \& Pattnaik, C. (2011). Learning Before Making the Big Leap Acquisition Strategies of Emerging Market Firms. Management International Review, 51, 461-481.

FICCI (2006). Study conducted on 306 foreign acquisitions by Indian firms from January 2000 to June 2006.

FICCI and Grant Thornton (2010). Investing in the European Union - lists the M\&A by Indian MNEs in the European Union during 2005 to 2010.

Fornell, C., \& Larcker, D. F. (1981). Evaluating Structural Equation Models with Unobserved Variables and Measurement Error. Journal of Marketing Research, XVIII, 39-50.

Frost, T. S., \& Zhou, C. (2005). R\&D Co-Practice and 'Reverse' Knowledge Integration in Multinational Firms. Journal of International Business Studies, 36, 676-687.

Furu, P. (2001). Drivers of competence development in different types of multinational R\&D subsidiaries. Scandinavian Journal of Management, 17, 133-149.

Garcia-Manjon, J. V., \& Elena Romero-Merino, M. (2012). Research, development, and firm growth. Empirical evidence from European top R\&D spending firms. Research Policy, 41, 1084-1092.

Gassmann, O., \& von Zedtwitz, M. (1999). New concepts and trends in international R\&D organization. Research Policy, 28, 231-250.

Gaur, A., \& Kumar, V. (2010). Internationalization of emerging market firms: a case for theoretical extension, in Devinney T., Pedersen T., Tihanyi L. (ed.) The Past, Present and Future of International Business \& Management (Advances in International Management, Volume 23), Emerald Group Publishing Limited, pp.603-627.

Gert, B. (2010). Tata Motor's transformational resource acquisition path: A case study of latecomer catch-up in a business group context. Working Papers of the Institute of Management Berlin at the Berlin School of Economics and Law (HWR Berlin), 55.

Girod, S. J., Belin, J. B., \& Thomas, R. J. (2009). Are emerging market multinationals creating the global models for the future? Accenture Institute for High Performance.

Grant, R. M. (1996). Toward a Knowledge-Based Theory of the Firm. Strategic Management Journal, 17, 109-122.

Guillen, M. F., \& Garcia-Canal, E. (2009). The American model of the multinational firm and the 'new' multinationals from emerging economies. Academy of Management Perspectives, 23, 23-35. 
Gupta, A. K., \& and Wang, H. (2009). The Rise of Global Champions: Impact of Country, Industry \& Company Effects, Indian Journal of Industrial Relations, 45(1), 115-126.

Gupta, A. K., \& Govindarajan, V. (1991). Knowledge Flows and the Structure of Control within Multinational Corporations. Academy of Management Review, 16, 768-792.

Gupta, A. K., \& Govindarajan, V. (1994). Organizing for Knowledge Flows within MNEs. International Business Review, 3(4), 443-457.

Gupta, A. K., \& Govindarajan, V. (2000). Knowledge Flows within Multinational Corporations. Strategic Management Journal, 21, 473-496.

Hair, J. F., Black, W. C., Babin, B. J., \& Anderson, R. E. (1995). Multivariate Data Analysis. Pearson Education Inc, New Jersey.

Hakanson, L., \& Nobel, R. (2001). Organizational Characteristics and Reverse Technology Transfer, Management International Review, 41(4), 395.

Harzing, A.-W., \& Noorderhaven, N. (2006). Knowledge flows in MNEs: An empirical test and extension of Gupta and Govindarajan's typology of subsidiary roles. International Business Review, 15, 195-214.

Hennart, J-F. (2012). Emerging market multinationals and the theory of the multinational enterprise. Global Strategy Journal, 2(3), 168-187.

Hofstede, G. (1980). Culture's consequences. Sage, Beverly Hills.

Jormanainen, I., \& Koveshnikov, A. (2012). International Activities of Emerging Market Firms A Critical Assessment of Research in Top International Management Journals. Management International Review, 52, 691-725.

Kale, P. (2009). The Global Indian Firm: Growth \& Value Creation through Overseas Acquisitions, Indian Journal of Industrial Relations, 45(1), 41-53.

Kale, P., Singh, H., \& Raman, A.P. (2009). Don't integrate your acquisitions, partner with them. Harvard Business Review, 87(12), 109-119

Kedia, B., Gaffney, N., \& Clampit, J. (2012). EMNEs and Knowledge-seeking FDI. Management International Review, 52, 155-173

Khanna, T. \& Palepu, K. G. (2006). Emerging giants: building world-class companies in developing countries. Harvard Business Review, 84, 2-10

Kogut, B., \& Singh, H. (1988). The effect of national culture on the choice of entry mode. Journal of International Business Studies, 19(3), 411-432.

Kumar, N. (2008). Internationalization of Indian Enterprises: Patterns, Strategies, Ownership Advantages, and Implications. Asian Economic Policy Review, 3, 242-261.

Kumar, V. \& Singh, N. (2008). Internationalization and performance of Indian pharmaceutical firms. Thunderbird International Business Review, 50 (5): 321-330. 
Lee, H., \& Choi, B. (2003). Knowledge management enablers, processes, and organizational performance: an integrative review and empirical examination. Journal of Management Information Systems, 20(1), 179-228.

Li, L. (2005). The effects of trust and shared vision on inward knowledge transfer in subsidiaries' intra- and inter-organizational relationships. International Business Review, 14, 77-95.

Li, L., Barner-Rasmussen, W., \& Bjorkman, I. (2007). What Difference Does the Location Make?: A Social Capital Perspective on Transfer of Knowledge from Multinational Corporation Subsidiaries Located in China and Finland. Asia Pacific Business Review, 13 (2), 233-249.

Li, P. P. (1998). The Evolution of Multinational Firms from Asia. Journal of Organizational Change Management, 11, 321-337.

Li, P. P. (2003). Toward a geocentric theory of multinational evolution: the implications from the Asian MNEs as latecomers. Asia Pacific Journal of Management, 20(2), 217242.

Luo, Y., \& Tung, R. L. (2007). International expansion of emerging market enterprises: A springboard perspective. Journal of International Business Studies, 38, 481-498.

Madhok, A., \& Keyhani, M., (2012). Acquisitions as entrepreneurship: asymmetries, opportunities, and the internationalization of multinationals from emerging economies. Global Strategy Journal, 2, 26-40.

Mathews, J. A. (2006). Dragon multinationals: New players in 21st century globalization. Asia Pacific Journal of Management, 23, 5-27.

McGuinness, M., Demirbag, M. \& Bandara, S. (2013) Towards a multi-perspective model of reverse knowledge transfer in MNEs, European Management Journal, 31(2):179-195.

Mellahi, K. \& Collings, D.G. (2010). The barriers to effective global talent management: the example of corporate élites in MNEs, Journal of World Business, 45 (2), 143-149.

Minbaeva, D. B. (2005). HRM practices and MNC knowledge transfer. Personnel Review, 34(1), 125-144.

Minbaeva, D. B. (2007). Knowledge Transfer in Multinational Corporations. Management International Review, 47(4), 567 - 593.

Minbaeva, D. B., Pedersen, T., Bjo“rkman, I., Fey, C. F., \& Park, H. J. (2003). MNC knowledge transfer, subsidiary absorptive capacity, and HRM, Journal of International Business Studies, 34, 586-599.

Monteiro, L. F., Arvidsson, N., \& Birkinshaw, J. (2008). Knowledge Flows within Multinational Corporations: Explaining Subsidiary Isolation and Its Performance Implications. Organization Science, 19(1), 90-107.

Muthusamy, S. K., \& White, M. A. (2005). Learning and Knowledge Transfer in Strategic Alliances: A Social Exchange View. Organization Studies, 26(3), 415-441. 
Nahapiet, J., \& Ghoshal, S. (1998). Social capital, intellectual capital, and the organizational advantage. Academy of Management Review, 23, 242-266.

Nayyar, D. (2008). The Internationalisation of Firms from India: Investment, Mergers and Acquisitions. Oxford Development Studies, 36(1), 111- 131.

Nunnally, J. (1978). Psychometric theory, 2nd ed. McGraw-Hill, New York.

Pak, Y. S., \& Park, Y-R. (2004). A Framework of Knowledge Transfer in Cross-border Joint Ventures - An Empirical Test of the Korean Context. Management International Review, 44(4), 417.

Pérez-Nordtvedt, L., Kedia, B. L., Datta, D. K., \& Rasheed, A. A. (2008). Effectiveness and Efficiency of Cross-Border Knowledge Transfer: An Empirical Examination. Journal of Management Studies, 45(4), 714-744.

Persson, M. (2006). The impact of operational structure, lateral integrative mechanisms and control mechanisms on intra-MNE knowledge transfer. International Business Review, 15, 547-569.

Pillai, K. G. (2006). Networks and competitive advantage: a synthesis and extension, Journal of Strategic Marketing, 14(2), 129-145.

Pradhan, J. P. (2007). Trends and Patterns of Overseas Acquisitions by Indian Multinationals, MPRA Paper, http://mpra.ub.uni-muenchen.de/12404/.

Prahalad, C. K., \& Hamel, G. (1990). The Core Competence of the Corporation. Harvard Business Review.

Rabbiosi, L. (2011). Subsidiary roles and reverse knowledge transfer: An investigation of the effects of coordination mechanisms. Journal of International Management, 17(2), 97113.

Ramamurti, R. (2009). What Have We Learned About Emerging-Market MNEs? In Ravi Ramamurti and Jitendra Singh (eds.) Emerging Multinationals from Emerging Markets. Cambridge UK: Cambridge University Press, Chapter 13.

Ramamurti, R. (2012). What is really different about emerging market multinationals? Global Strategy Journal, 2, 41-47.

Ray, S., \& Gubbi, S. R. (2009). International Acquisitions by Indian Firms: Implications for Research on Emerging Multinationals, Indian Journal of Industrial Relations, 45(1), 11-26.

Richey, R. G., \& Autry, C. W. (2009). Assessing interfirm collaboration/technology investment tradeoffs - The effects of technological readiness and organizational learning. The International Journal of Logistics Management, 20(1), 30-56.

Ringle, C. M., Wende, S., \& Will, A. (2005). SmartPLS 2.0, http://www.smartpls.de.

Rugman, A. M. (2008). How global are TNCs from emerging markets? in Karl Sauvant, ed., The Rise of Transnational Corporations from Emerging Markets: Threat or Opportunity (Cheltenham, UK: Elgar), 86-106. 
Rugman, A. M., \& Verbeke, A. (1993). Generic strategies in global competition. In Rugman, A. M. \& Verbeke, A. (Eds.). Research in Global Strategic Management, Volume 4: Global Competition: Beyond the Three Generics, JAI Press: Greenwich, CT, 3-16.

Schulz, M. (2003). Pathways of Relevance: Exploring Inflows of Knowledge into Subunits of Multinational Corporations. Organization Science, 14(4), 440-459.

Schulz. M. (2001). The Uncertain Relevance of Newness: Organizational Learning and Knowledge Flows. The Academy of Management Journal, 44(4), 661-681.

Sethi, D. (2009). Are multinational enterprises from the emerging economies global or regional? European Management Journal, 27, 356-365.

Simonin, B. L. (1999a). Ambiguity and the Process of Knowledge Transfer in Strategic Alliances. Strategic Management Journal, 20(7), 595-623.

Simonin, B. L. (1999b). Transfer of Marketing Know-How in International Strategic Alliances: An Empirical Investigation of the Role and Antecedents of Knowledge Ambiguity. Journal of International Business Studies, 30(3), 463-490.

Simonin, B. L., \& Özsomer, A. S. (2009). Knowledge Processes and Learning Outcomes in MNCs: An Empirical Investigation of the Role of HRM Practices in Foreign Subsidiaries. Human Resource Management, 48(4), 505- 530.

Szulanski, G. (1996). Exploring Internal Stickiness: Impediments to the Transfer of Best Practice within the Firm. Strategic Management Journal, 1, 27-43.

Taifi, N., \& Passiante, G. (2012). Speeding up 'New Products and Service Development' through strategic community creation: case of automaker after-sales services partners. The Service Industries Journal, 32(13), 2115-2127.

Tsai, W., \& Ghoshal, S. (1998). Social capital and value creation: the role of intrafirm networks. Academy of Management Journal, 41, 464-476.

UNCTAD (2012). World Investment Report 2012: Towards a New Generation of Investment Policies, United Nations: New York.

WIR (2010) - UNCTAD World Investment Report.

Yang, Q., Mudambi, R., \& Meyer, K. E. (2008). Conventional and Reverse Knowledge Flows in Multinational Corporations. Journal of Management, 34, 882.

Zaheer, S. (1995). Overcoming the Liability of Foreignness. The Academy of Management Journal, 38(2), 341-363.

Zander, U., \& Kogut, B. (1995). Knowledge and the speed of the transfer and limitation of organizational capabilities: An empirical test. Organization Science, 6(1), 76-92. 


\section{Appendix A - Scales}

$\underline{\text { Knowledge Complexity }}$

- Your subsidiary's knowledge is the product of many interdependent techniques, routines, individuals and resources (Items Know_Compl1, Know_Compl2 and Know_Compl3 for technical, marketing and managerial knowledge respectively)

\section{Collaboration}

- $\quad$ Both Parent and Subsidiary work together to share new ideas (Collab1)

- Both Parent and Subsidiary frequently share proprietary information with one another (Collab2)

- Both Parent and Subsidiary work together to take advantage of new opportunities (Collab3)

- $\quad$ Both Parent and Subsidiary work together toward common goals (Collab4)

\section{$\underline{\mathrm{RKT}}$}

- $\quad$ Our subsidiary provides us with knowledge and skills in (Items Rev_Flow1, Rev_Flow2 and Rev_Flow3 for technical, marketing and managerial knowledge respectively)

\section{$\underline{\text { Absorptive Capacity }}$}

- We have the academic background to understand our subsidiary's knowledge

- We have better capabilities for adopting new techniques than our competitors

- We provide various education programs for employees

- We allocate financial resources for new ideas and research

- We provide frequent training programs abroad 
Table 1. Respondent characteristics

\begin{tabular}{|c|c|c|c|}
\hline Description & Percentage & Description & Percentage \\
\hline Industry - Sector & & Subsidiary Location & \\
\hline $\begin{array}{l}\text { Pharma, Biotech \& } \\
\text { Healthcare }\end{array}$ & 20 & USA & 32 \\
\hline IT \& ITeS & 17 & UK & 19 \\
\hline Automotives & 12 & Germany & 9 \\
\hline $\begin{array}{l}\text { Chemicals, Fertilizers \& } \\
\text { Plastics }\end{array}$ & 11 & Canada & 3 \\
\hline Metals, Ores \& Mining & 11 & Australia & 2 \\
\hline Engineering \& Machinery & 7 & France & 2 \\
\hline $\begin{array}{l}\text { Textiles, Apparels \& } \\
\text { Jewelry }\end{array}$ & 5 & Rest of Europe & 18 \\
\hline Electrical \& Electronics & 4 & Others & 15 \\
\hline Oil, Gas \& Power & 3 & Subsidiary Age & \\
\hline Telecom & 3 & $<10$ years & 30 \\
\hline Others & 7 & $10-20$ years & 15 \\
\hline MNE age (parent) & & $20-30$ years & 39 \\
\hline$<10$ years & 6 & $30-50$ years & 4 \\
\hline $10-20$ years & 28 & $50-100$ years & 8 \\
\hline $20-30$ years & 29 & $>100$ years & 4 \\
\hline $30-50$ years & 17 & Respondent Position & \\
\hline $50-100$ years & 12 & Senior Management & 71 \\
\hline$>100$ years & 8 & Middle Management & 29 \\
\hline No. of employees (Parent) & & $\begin{array}{l}\text { Respondent Experien } \\
M N E\end{array}$ & with the \\
\hline$<1000$ & 29 & $>20$ years & 8 \\
\hline $1000-5000$ & 43 & $15-20$ years & 13 \\
\hline $5000-10,000$ & 9 & 10 - 15 years & 17 \\
\hline$>10,000$ & 19 & $\begin{array}{l}5-10 \text { years } \\
<5 \text { years }\end{array}$ & $\begin{array}{l}29 \\
33\end{array}$ \\
\hline
\end{tabular}


Table 2. Reliability and validity of measures

\begin{tabular}{llcccc}
\hline Constructs & Items & $\begin{array}{c}\text { Outer } \\
\text { Loading }\end{array}$ & AVE & CR & $\begin{array}{c}\text { Cronbach's } \\
\text { alpha }\end{array}$ \\
\hline \multirow{2}{*}{ Knowledge Complexity } & Know_Compl1 & 0.7595 & & & \\
& Know_Comp12 & 0.8952 & 0.7144 & 0.8819 & 0.7981 \\
& Know_Comp13 & 0.8747 & & & \\
& Rev_Flow1 & 0.7881 & & & \\
Reverse Knowledge Flow & Rev_Flow2 & 0.8823 & 0.728 & 0.889 & 0.8117 \\
& Rev_Flow3 & 0.8858 & & & \\
Collaboration & Collab1 & 0.8801 & & & \\
& Collab2 & 0.7663 & 0.744 & 0.9205 & 0.8844 \\
& Collab3 & 0.9066 & & & \\
\hline
\end{tabular}


Table 3. Descriptive statistics and correlation matrix

\begin{tabular}{|c|c|c|c|c|c|c|c|c|c|c|c|c|c|}
\hline Variables & Mean & $\begin{array}{l}\text { Std. } \\
\text { Dev. }\end{array}$ & 1 & 2 & 3 & 4 & 5 & 6 & 7 & 8 & 9 & 10 & 11 \\
\hline 1. Rev. Knowl. Flow & 4.81 & 1.288 & 1 & & & & & & & & & & \\
\hline 2. Org. Collab & 5.89 & .985 & $.508^{* *}$ & 1 & & & & & & & & & \\
\hline 3. Rel. WEF score & 1.22 & .095 & .038 & -.016 & 1 & & & & & & & & \\
\hline 4. Abs. Capacity & 5.33 & .988 & $.475^{* *}$ & $.469^{* *}$ & .044 & 1 & & & & & & & \\
\hline 5. Int. Exp & 14.06 & 13.12 & .133 & -.009 & .011 & .184 & 1 & & & & & & \\
\hline 6. Cult. Distance & 1.49 & .535 & $-.221^{*}$ & .008 & $.391^{* *}$ & -.038 & .110 & 1 & & & & & \\
\hline 7. Parent Comp. Size & 11678 & 44439 & .128 & -.002 & .036 & .146 & $.469^{* *}$ & -.050 & 1 & & & & \\
\hline 8. Parent Comp. Age & 37.19 & 36.75 & .171 & -.001 & -.034 & .183 & $.365^{* *}$ & -.008 & .057 & 1 & & & \\
\hline 9. Sub. Age & 27.34 & 30.36 & .001 & -.090 & .131 & -.071 & .034 & $.218^{*}$ & -.042 & .127 & 1 & & \\
\hline 10. Sub. Size & 937 & 2615 & .037 & .016 & .074 & .079 & .078 & .071 & .089 & .088 & -.043 & 1 & \\
\hline 11. Knowl. Complexity & 5.049 & 1.140 & $.633^{* *}$ & $.504^{* *}$ & -.085 & $.444^{* *}$ & .115 & -.081 & .161 & .136 & -.085 & .189 & 1 \\
\hline
\end{tabular}

$N=101,2-$ tailed Spearman's correlation test. $* p \leq .05$, **p $\leq .01$ 
Table 4. OLS regression models (Dependent variable is RKT)

\begin{tabular}{|c|c|c|c|}
\hline & Model 1 & Model 2 & Model 3 \\
\hline (Constant) & 1.521 & $-3.350^{*}$ & $-5.317 * *$ \\
\hline \multicolumn{4}{|l|}{$\underline{\text { Control Variables }}$} \\
\hline Absorptive Capacity of parent & $.593^{* * * * *}$ & .139 & .168 \\
\hline Log of International Experience & $-.740^{\wedge}$ & -.330 & -.327 \\
\hline Log of Parent Comp Size & .240 & .240 & .254 \\
\hline Log of Parent Comp Age & 679 & .342 & .330 \\
\hline Log of Subsidiary Age & .024 & -.063 & -.118 \\
\hline Log of Subsidiary size & -.102 & -.124 & -.109 \\
\hline High technology industry & $.742^{\wedge}$ & .176 & .120 \\
\hline Med technology industry & .381 & .007 & -.081 \\
\hline Greenfield subsidiaries & -.315 & 655 & .722 \\
\hline Brownfield subsidiaries & -.494 & .595 & .664 \\
\hline Cultural Distance &.$- .504^{*}$ & $-.619^{* * *}$ & $-.578^{* *}$ \\
\hline \multicolumn{4}{|l|}{ Independent Variables } \\
\hline Knowledge Complexity & & $.491^{* * * * *}$ & $.470^{* * * *}$ \\
\hline Collaboration & & $.265^{*}$ & $.631^{*}$ \\
\hline Subs with world mandate & & .394 & .454 \\
\hline Subs are specialised contributor & & $.468^{\wedge}$ & $.452^{\wedge}$ \\
\hline Relative WEF score & & $2.245^{*}$ & $2.000^{\wedge}$ \\
\hline \multicolumn{4}{|l|}{ Moderating Effects } \\
\hline Collab $\mathbf{X}$ High Tech industry & & & $.515^{\wedge}$ \\
\hline Collab $\mathbf{X}$ Med Tech industry & & & .414 \\
\hline $\mathrm{R}^{2}$ & .326 & .579 & .595 \\
\hline Adj. $R^{2}$ & .243 & .499 & .506 \\
\hline $\mathrm{F}$ & $3.920^{* * * *}$ & $7.233^{* * * *}$ & $6.7^{* * * * *}$ \\
\hline
\end{tabular}


